\title{
The Role of Foreign Language Culture on Teaching the Language and Learner Motivation
}

\author{
Bunyamin Celik $^{1} \&$ Yunus Y1ld12 \\ ${ }^{1 \& 2}$ Faculty of Education, Tishk International, Erbil, Iraq \\ Correspondence: Bünyamin Celik, Tishk International University, Erbil, Iraq. \\ Email: bunyamin.celik@ishik.edu.iq
}

Received: April 3, 2019

Accepted: May 24, 2019

Online Published: June 1, 2019

doi: 10.23918/ijsses.v5i4p150

\begin{abstract}
People are living in different places in the world and the way of life and the customs of these groups of people directly affect the communication between them. Therefore, the cultures of society and the language they use are two important things that constitute them and do not separate from each other. Motivation, which is one of the factors affecting success in secondary or foreign language learning, is defined as a driving force that initiates, directs, and then sustains the learning process (Clement, Dörnyei \& Noels, 1994; Pintrich \& Schunk, 1996). In the process of learning a new foreign language, cultural elements in the target language motivates the student positively and facilitates learning the knowledge more easily and efficiently. Considering the importance of this issue, this study was carried out by separating two groups of 40 students at the Upperintermediate Level in Iraq Ishik University Preparatory School. With assessing both groups' scores and outcomes of the progress tests of the course-book for 12 weeks and by taking into consideration the evaluation of the written feedbacks about the method after the application, the importance of the target foreign language culture and the contribution to the student motivation are shown.
\end{abstract}

Keywords: Teaching of language, Culture, Motivation, Foreign Language

\section{Introduction}

Foreign language teaching, which has felt like a necessity since the beginning of international relations, has become even more important nowadays. Given the benefits that a foreign language can provide to a person, it is argued that this feature and acquisition will enable the person to better understand the world, to overcome cultural and linguistic barriers and to have a profession (Odabaş1, 1997). In addition, foreign language also gives the opportunity to acquire knowledge at a higher level, to reach the knowledge, culture and accumulation of the members of that language and to deal with the speakers of the target language. Therefore, while learning a new foreign language, we should learn the culture of the country where that language is spoken. We cannot learn literally by separating cultural items and learning only the target foreign language structurally, by learning the theories and grammatical rules of words. These and similar assumptions generally engage the minds of social engineers, linguists, foreign language educators, and even foreign language learners, and encourage them to seek new solutions and analysis, especially in the globalized world after the Second World War. Whether to think from an educational perspective or political interactions, you can achieve results.

The purpose of this study, especially when examined in terms of foreign language acquisition, will be to focus on which extent learning target language's culture play a part and the effects of cultural factors on student motivation when acquiring the target language. 
The intense interest in foreign language teaching in many countries around the world places great pressure on educators. Many teaching methods and approaches such as the grammar translation method, communicative methods, functional language teaching that have been used for many years led to the fact that the language cannot been fully taught. For this, some educators have claimed the inclusion of cultural teaching materials in addition to these. Besides getting rid of the negativities above all else in order to get over the problems which are generally known in the acquisition and teaching of foreign languages, it is also necessary to look for ways to increase the level of love to language and to improve the interest to the course. Here we are confronted with the phenomenon called motivation because the motivated student can keep off the unwanted things during teaching and can focus on language learning (Yavuz, 1999).

It seems possible to claim this following idea from what is discussed. It is not at all a correct approach to keep the language completely separate from culture while acquiring a language, to fully teach and understand it. Learning the cultural meaning and feelings of the target language will also bring the learner's sympathy towards the target language as well as the student's learning motivation to the highest level.

Students cannot abstract themselves from learning many expressions such as idioms, proverbs, metaphors, similes, whatever language they learn. Although some learner approaches say "I only learn a language, I do not want to learn its culture", it is not beneficial for language learning and effective student motivation to avoid learning the linguistic and cultural expressions. When culture elements are not taught sufficiently, there can be nothing but the expression of a foreign language by the student the concepts he sees from his cultural frame with different symbols (Brooks, 1986).

One would be pleased when a different language and cultural learner learn your mother tongue and use your culturally related expressions. Culture specific expressions like "God bless you", "take it easy", "I was not born yesterday!", "Get better soon!", "I am sorry to hear of your loss" and their pragmatic use is what you expect from someone who learns your language and you will be pleased to hear it. This fact supports the argument that language and culture cannot be separated from one another and that this should be taken into account when learning or teaching the language.

\section{Culture and Language Relation in Foreign Language Teaching}

Culture is a difficult term to define. In 1952, American anthropologists, Kroeber and Kluckhohn critically examined the concepts and definitions of culture and compiled a list of 164 different definitions. Apte (1994, p. 2001), the first word that comes to our mind when it is generally called "culture" is "society". Whether it is written or verbal culture, we have to talk about a community.

Here are some of the different understandings of culture;

1. "Culture... is that complex whole which includes knowledge, belief, art, morals, law, custom, and any other capabilities and habits acquired by man as a member of society" Tyler (British Anthropologist) 1870; and cited by Avruch 1998.

2. Culture, which may be seen as an organized activity, learned or created by members of a community, may incorporate the experiences as well as images or encodements passed on from earlier generations, learned from a social group, or may originate from individuals themselves (Zegarac, 2007). 
3. 'Culture is a fuzzy set of basic assumptions and values, orientations to life, beliefs, policies, procedures and behavioral conventions that are shared by a group of people, and that influence (but do not determine) each member's behavior and his/her interpretations of the 'meaning' of other people's behavior.' (Spencer-Oatey 2008, p. 3)

According to the definition of culture in general terms, there are two dimensions. The first one covers artworks belonging to the society, literature and elements of daily life. The second includes concepts such as behavioral forms and beliefs shared by members of society, and ways of thinking. In other words, culture is to consciously or unconsciously realize that thoughts and values shared by a broad base are true or false. In short, culture is the whole of the material and spiritual characteristics that a society produces in its historical process and transfers to other generations, and it is a collective peculiarity that reflects the religion, lifestyle and thinking style of that society.

The ability to convey emotions and thoughts to others, to understand what is read and to think straight is dependent on the ability to use the language (İşeri, 1996). From another point of view this can be seen as "one who does not know a foreign language, does not know its own language" (Goethe). So the culture is one of the important means. Language, Sapir (1970) noted, "a guide to social reality" and a "symbolic guide to culture". Thanks to language, every subject related to culture can be transmitted to other generations, both verbally and in written. According to many linguists, language and culture cannot be distinguished from each other as mentioned above. Whether explaining written or verbal culture, the language is spoken and its community are mentioned. Language is one of the basic elements that constitute a nation apart from being a basic means of communicating between people.

Language, which has such an active role in the lives of societies, has an important share in cultural transfer and cultural relations. This issue is particularly felt in the foreign language teaching and learning process. In fact, it is possible to say that language is culture and culture is language when you think in broad sense. In order to be able to speak a language, it is important to know the culture in terms of effective and healthy communication.

The fact that language and culture are inextricably linked together has become one of the topics that have been increasingly emphasized day by day in foreign language teaching. The aim of learning a foreign language is to communicate through that language. But a structurally learned language to communicate cannot be said to have given too much to the speaker. Since the cultures in which humans are trained are different from each other, knowing each other's culture will facilitate communication, avoid possible misunderstandings and problems that may arise. That is why, when teaching a foreign language, teaching the culture elements of that language should be kept in the foreground. Cultural understanding has a crucial role in intercultural interactions. In terms of intercultural communication, it means that language knowledge must pay attention to how communication is carried out in the target culture and the sociocultural aspects that are important for enhancing the cultural awareness of the students (Byram, 1989).

Halliday (1978) defines language as a "social indicator" of culture, and says that every language reflects concepts such as lifestyle, way of thinking, and so on. Issues such as "how the Chinese talk in certain situations", "what the British think in what context" and "how the Japanese respond" can only be related to the culture of that country, and learning the phrases expressed in this context also obliges them to learn the culture of the country concerned. 


\section{Usage of Cultural Elements in Foreign Language Teaching and its Contribution to Student Motivation}

It is known that the learning environment that aims to increase motivation with high motivation of the learners affects the learning positively, while the factors which are supposed to negatively affect the motivation with low motivation cause to be defined as failures such as not reaching the academic targets.

There are pioneering studies under the heading of "Attitudes and motivation in second language learning" based on the social-psychological approach of Gardner and Lambert (1972) at the starting points of studies on the role of motivation in language learning in general up to 90`s in general. According to the approach, language learning is different from learning any other lesson; language is a part of the identity of the individual and is used in social relations that are in the foreground of your identity. Therefore, beyond learning the rules or certain skills, it requires learning and embracing in some settings the social and cultural behavior of the community to which the language belongs. In this context, it is thought that the success of foreign language learning is closely related to the person`s approach to the language-speaking community. After 90`s, an innovative approach to the role of motivation in language learning is seen (Brown, 1994, Crookes \& Schmidt, 1991, Dörnyei, 1994a, 1994b; Oxford \& Shearin, 1994, Skehan, 1991). This approach, which they call "motivational renaissance" by Gardner and Trem'blay (1994, p. 524), focuses on the perceptions of teachers about motivation in empirical research and the reflection of these perceptions on classroom practices and in the recent years researches on motivation theories of educational psychology and second language education tries to fill the gap between practices.

Over time, these and similar approaches to language motivation in foreign language teaching have varied according to the student and teacher profile, learning environment, different settings and cultures. But in general, a common point is seen when different approach of motivation research and education psychology that all of the students are motivated to learn in a suitable environment and it is possible to provide this environment in the classroom (McCombs \& Pope, 1994). For example, Dörnyei and Otto (1998) have developed a motivational taxonomy that includes motivation strategies for the core issues of preparing motivation to use in practice, establishing positive relationships with students, attracting students to class activities, and assisting the student in self-evaluation and development. It is clear that in the learning environment, student motivation tends to increase positively, especially when the culture of language is used, the student can express himself / herself on the target language, and when the technical background is set in a ready-made learning environment or a class. These combinations and regulations constitute an important place in foreign language education.

In addition to this, another important point in practice is that some important features of the use of cultural items during the target foreign language learning should be considered by the trainers. According to Straub (1999), students who know their own cultures can be more objective while evaluating the target culture knowing their values, traditions, rituals and lifestyles in the culture. According to the age and level of the student, such activities can be given in different forms. Particularly for children who are new to the school and who are new to the environment, the subjects of their own culture, such as national sports, religious or national holidays, ceremonies, important days, and songs must be learnt. After they have been sufficiently processed, similar subjects in the culture of the target language can be processed and cultural interaction can be provided in foreign language learning. 
'Beginning foreign language students want to feel, touch, smell, and see the foreign peoples and not just hear their language' (Peck, 1998). At any rate, the foreign language classroom should become a 'cultural island' (Kramsch, 1993; Singhal, 1998; Peck, 1998), where the accent will be on 'cultural experience' rather than 'cultural awareness' (Byram \& Morgan, 1994, pp. 55-60). From the first day, teachers are expected to bring in the class posters, pictures, maps, and other realia in order to help students develop 'a mental image' of the target culture (Peck, 1998).

Thus, they incorporate students into the learning process. In addition, using materials such as the internet, specific intelligent board applications, song and poetry, rhymes, newspapers and magazines and films can make learning easier and provide learners with knowledge about the target culture. In addition to these, groups within the class can be created about the music, weddings, clothing, distinct gestures and mimics, weather conditions, important days, architectural structures and touristic sites, historical heroes and activities can be organized in the classroom and cultural items can be utilized in foreign language teaching.

Students or guests who have been to the country where the foreign target language is spoken may be asked to bring information about the target culture. Both in-class and out-of-class activities should be held to help students become more knowledgeable about the target foreign language culture and their own cultures, with comparative projects, research, etc. that will help them compare the two cultures. Whether it is a group or a project activity, such activities will enable the student to learn or reinforce his or her own culture during the target culture search. Thanks to the many international project organizations, especially from primary education to high school, many students and teachers are able to go abroad and obtain knowledge about the lifestyles where the target foreign language is spoken.

\section{Research Methodology}

\subsection{Organization of Research}

The target population of this research is Ishik University Preparatory School students'. For this research two groups were needed: control group and experimental group. All academic or non-courses in departments at Ishik University are taught in English. Therefore, after being admitted to university students have an international placement test in the English language.

The main goal of the international placement test in English is to decide on their level of English. Students, depending on their scores of the international placement test, are placed in different English course levels. Hereby, it was ensured that the English language level of the students in both control and experimental groups were more or less the same. Two groups of students were chosen randomly in this research after getting the required permission from the Ishik University administration and each group contained 20 students so totally 40 students were selected in this research and also students in both groups were selected from the same English course level.

This research was a-twelve-week program. The students in both groups were formed from upperintermediate level from four groups. The learners at upper-intermediate level (The Common European Framework of Reference for Languages B2 level - Vantage) in the study had been exposed to most of the general grammatical structures in English before they came to preparatory school at university, and these students are able to understand the main ideas of complex text on both concrete and abstract topics, including technical discussions in his or her field of specialization. Selecting participants from the same level would be more convenient and more reasonable to obtain the best information and feedbacks. 
Students who participated the research were chosen randomly; no criteria were followed in forming the groups. Students were chosen spontaneously based on their own willingness; so, students were voluntary participants. In addition, gender and ethnicity is another ethical issue in this program. Both boys and girls participated the research and there were international students as well. This research would not make any comparisons concerning the scores of learners from different genders and nations. The lecturer had a friendly relationship with all students throughout the research. The lecturer's main role in this research was to comfort and encourage students.

\subsection{Experiment}

In the experiment, two separate classes were created for the control and experimental groups, and 20 students in each class constituted 40 students in total. Face 2 Face Upper - Intermediate Student Book Second Edition, consisting of 12 units from the Cambridge publishing house with the same curriculum in both classes. And workbooks were taught 144 hours in total for 12 weeks, 12 hours a week. Within 12 weeks, the average of the weekly Cambridge Face 2 Face Upper-Intermediate Second Edition Progress Tests of the 12 units that belonged to the book itself were evaluated at the end of each unit were compared. All the tests were evaluated over 100 points.

The classroom where the control group was educated had a white board, an intelligent board-computer combination that runs the iTunes program, an ordinary training environment consisting of rows and chairs. The students were educated at the limits prescribed by the publishing house and the course book.

The class of the experimental group students also had the same elements in the classroom as the control group; the whiteboard, the intelligent board-computer combination, the I-Tunes program. In addition, they had the posters and banners of the target language grammar and vocabulary on the walls of the classroom other than the rows and columns. In addition, starting from the door of the classroom, there were American and English paintings, in some corners and suitable places, and trinkets and sculptures of certain sizes, models, porcelain tea sets etc. which are the cultural items of the target language. In addition to these, in a small part of the course every two weeks we heard about the impressions of our students going to America and England, especially about some of the cultural and famous places or structures mentioned in the book. Sometimes the parents of our own students, relatives and friends were invited to the class since they visited these places. Small-scale interviews were organized without exceeding the designated class hours and the curriculum. Again, the students in the experimental group were given tasks and homework in some units of the book in order to get to know authors, movie stars, actresses, radio - television reporters better about the target language. This allowed the students in the experimental group to motivate the students about the cultural values and activities of the target language in addition to the curriculum that the publishing house anticipated.

\subsection{Student Feedback}

After 12 weeks of education, both classroom lecturers and students who participated in the experiment were evaluated in terms of the contribution of the method to student motivation and language learning in relation to the use of relevant cultural objects and objects in the classroom and in the classroom environment. 


\section{Results and Discussion}

12 weekly Cambridge Face 2 Face Upper Intermediate Second Edition Progress Tests of 12 units where students were evaluated at 12 weeks were compared with weekly averages of control and experimental groups.

12-week general averages of weekly Cambridge Face 2 Face Upper-Intermediate Second Edition Progress Tests of the 12 units of the Cambridge Face 2 Face Upper-Intermediate Second Edition coursebook that belonged to itself and the evaluations at the end of each unit within 12 weeks are shown in Table 1, 2, and 3 , respectively.

Table 1: General Average of Progress Tests for Control Group in 12 Weeks

\begin{tabular}{|l|c|c|c|c|c|c|c|c|c|c|c|c|}
\hline Student Names / Weeks & Week 1 & Week 2 & Week 3 & Week 4 & Week 5 & Week 6 & Week 7 & Week 8 & Week 9 & Week 10 & Week 11 & Week 12 \\
\hline Student 1 & 60 & 67 & 69 & 72 & 84 & 80 & 75 & 73 & 62 & 64 & 76 & 70 \\
\hline Student 2 & 71 & 74 & 72 & 78 & 76 & 92 & 98 & 63 & 74 & 82 & 77 & 85 \\
\hline Student 3 & 51 & 68 & 62 & 66 & 71 & 84 & 55 & 62 & 68 & 74 & 72 & 67 \\
\hline Student 4 & 82 & 73 & 59 & 88 & 82 & 86 & 72 & 74 & 74 & 67 & 81 & 90 \\
\hline Student 5 & 72 & 62 & 67 & 74 & 79 & 81 & 83 & 77 & 74 & 62 & 70 & 66 \\
\hline Student 6 & 67 & 61 & 74 & 71 & 77 & 78 & 81 & 66 & 68 & 60 & 78 & 69 \\
\hline Student 7 & 84 & 68 & 66 & 75 & 73 & 81 & 88 & 83 & 77 & 75 & 78 & 71 \\
\hline Student 8 & 77 & 71 & 67 & 66 & 68 & 62 & 67 & 76 & 71 & 62 & 66 & 77 \\
\hline Student 9 & 53 & 62 & 54 & 52 & 56 & 59 & 62 & 67 & 61 & 53 & 69 & 82 \\
\hline Student 10 & 62 & 68 & 71 & 55 & 58 & 62 & 69 & 73 & 74 & 62 & 60 & 55 \\
\hline Student 11 & 67 & 73 & 61 & 62 & 64 & 69 & 74 & 70 & 65 & 72 & 74 & 67 \\
\hline Student 12 & 73 & 61 & 68 & 72 & 55 & 67 & 62 & 69 & 71 & 74 & 70 & 69 \\
\hline Student 13 & 81 & 84 & 82 & 80 & 68 & 76 & 70 & 72 & 88 & 74 & 71 & 63 \\
\hline Student 14 & 48 & 69 & 60 & 64 & 75 & 81 & 70 & 63 & 69 & 61 & 76 & 71 \\
\hline Student 15 & 54 & 62 & 55 & 52 & 57 & 65 & 69 & 60 & 74 & 72 & 70 & 72 \\
\hline Student 16 & 77 & 81 & 80 & 67 & 69 & 74 & 83 & 82 & 84 & 74 & 77 & 75 \\
\hline Student 17 & 64 & 69 & 71 & 72 & 77 & 69 & 76 & 83 & 88 & 76 & 87 & 93 \\
\hline Student 18 & 83 & 73 & 71 & 73 & 78 & 81 & 84 & 71 & 79 & 82 & 70 & 75 \\
\hline Student 19 & 66 & 77 & 72 & 77 & 78 & 79 & 81 & 74 & 79 & 77 & 71 & 84 \\
\hline Student 20 & 71 & 63 & 69 & 63 & 62 & 66 & 78 & 68 & 70 & 66 & 74 & 74 \\
\hline Weekly Averages & $\mathbf{6 8}$ & $\mathbf{6 9}$ & $\mathbf{6 8}$ & $\mathbf{6 9}$ & $\mathbf{7 0}$ & $\mathbf{7 5}$ & $\mathbf{7 5}$ & $\mathbf{7 1}$ & $\mathbf{7 4}$ & $\mathbf{6 9}$ & $\mathbf{7 3}$ & $\mathbf{7 4}$ \\
\hline
\end{tabular}

Table 1 shows the 12-week long class and student achievement scores of the control group students over 100. As can be seen, the grade points in the first week were 68 out of 100, followed by 69 in the second week, 68 in the third week, 69 in the fourth week, 70 in the fifth week, 75 in the sixth and seventh weeks, 71 in the eighth week, 74 in the ninth week, 69 in the tenth week, 73 in the eleventh week and 74 in the 12th week. With 75 points in the sixth and seventh week, they are the most successful weeks for the control group. 
Table 2: General Average of Progress Tests for Experimental Group in 12 Weeks

\begin{tabular}{|c|c|c|c|c|c|c|c|c|c|c|c|c|}
\hline Student Names / Weeks & Week 1 & Week 2 & Week 3 & Week 4 & Week 5 & Week 6 & Week 7 & Week 8 & Week 9 & Week 10 & Week 11 & Week 12 \\
\hline Student 1 & 70 & 70 & 71 & 74 & 70 & 91 & 77 & 76 & 72 & 77 & 85 & 84 \\
\hline Student 2 & 73 & 70 & 82 & 76 & 73 & 90 & 80 & 70 & 82 & 87 & 90 & 87 \\
\hline Student 3 & 56 & 58 & 71 & 76 & 56 & 84 & 92 & 74 & 80 & 89 & 97 & 82 \\
\hline Student 4 & 81 & 87 & 69 & 83 & 81 & 85 & 72 & 76 & 90 & 82 & 90 & 85 \\
\hline Student 5 & 67 & 60 & 74 & 76 & 67 & 89 & 85 & 71 & 90 & 94 & 89 & 86 \\
\hline Student 6 & 77 & 82 & 88 & 77 & 77 & 82 & 91 & 88 & 86 & 90 & 91 & 90 \\
\hline Student 7 & 70 & 90 & 71 & 82 & 85 & 87 & 86 & 80 & 90 & 94 & 87 & 95 \\
\hline Student 8 & 71 & 85 & 74 & 70 & 71 & 73 & 76 & 76 & 77 & 88 & 95 & 85 \\
\hline Student 9 & 65 & 73 & 68 & 75 & 65 & 70 & 72 & 77 & 73 & 80 & 90 & 80 \\
\hline Student 10 & 66 & 77 & 76 & 70 & 66 & 76 & 79 & 70 & 74 & 82 & 92 & 81 \\
\hline Student 11 & 62 & 69 & 70 & 69 & 62 & 89 & 88 & 82 & 70 & 91 & 90 & 85 \\
\hline Student 12 & 72 & 79 & 68 & 84 & 79 & 80 & 83 & 80 & 70 & 90 & 87 & 92 \\
\hline Student 13 & 68 & 80 & 84 & 87 & 80 & 83 & 75 & 70 & 77 & 83 & 90 & 95 \\
\hline Student 14 & 59 & 66 & 77 & 82 & 59 & 75 & 79 & 71 & 81 & 87 & 85 & 83 \\
\hline Student 15 & 74 & 77 & 74 & 86 & 74 & 70 & 73 & 77 & 77 & 80 & 82 & 80 \\
\hline Student 16 & 82 & 88 & 83 & 78 & 82 & 84 & 93 & 85 & 71 & 90 & 88 & 85 \\
\hline Student 17 & 60 & 65 & 79 & 74 & 60 & 72 & 90 & 80 & 82 & 95 & 87 & 90 \\
\hline Student 18 & 80 & 81 & 73 & 87 & 80 & 76 & 80 & 71 & 84 & 90 & 80 & 94 \\
\hline Student 19 & 79 & 80 & 79 & 80 & 79 & 78 & 83 & 72 & 87 & 90 & 92 & 87 \\
\hline Student 20 & 67 & 70 & 82 & 75 & 67 & 74 & 77 & 71 & 79 & 94 & 90 & 85 \\
\hline Weekly Averages & 69 & 75 & 76 & 78 & 72 & 80 & 82 & 76 & 80 & 88 & 89 & 86 \\
\hline
\end{tabular}

Table 2 shows the 12-week class and student achievement scores of the experimental group students over 100. As can be seen, the grade points in the first week were 69 out of 100 , followed by 75 in the second week, 76 in the third week, 78 in the fourth week, 72 in the fifth week, 80 in the sixth week, 82 in the seventh week, 76 in the eighth week, 80 in the eighth week, 88 in the tenth week, 89 in the eleventh week and 86 in the twelfth week. With 89 points in the eleventh week, the control group is the most successful week for students.

Table 3: Total Group Averages for 12 Weeks

\begin{tabular}{|c|c|c|c|c|c|c|c|c|c|c|c|c|c|}
\cline { 2 - 13 } \multicolumn{1}{c|}{} & Week 1 & Week 2 & Week 3 & Week 4 & Week 5 & Week 6 & Week 7 & Week 8 & Week 9 & Week 10 & Week 11 & Week 12 & \multicolumn{2}{c|}{ Total group averages for 12 weeks } \\
\hline $\begin{array}{c}\text { Weekly Averages of } \\
\text { Control Group }\end{array}$ & 68 & 69 & 68 & 69 & 70 & 75 & 75 & 71 & 74 & 69 & 73 & 74 & 71 \\
\hline $\begin{array}{c}\text { Weekly Averages of } \\
\text { Experimental Group }\end{array}$ & 69 & 75 & 76 & 78 & 72 & 80 & 82 & 76 & 80 & 88 & 89 & 86 & \\
\hline
\end{tabular}

Table 3 compares the 12-week general test results of both groups and the control group's weekly average of the test was 71 out of 100 and the average of the experimental group was 79 .

\subsection{Experiment Result}

Table 1 shows the average of the weekly progressive test scores of the 20 students in the control group and the results of the weekly progressive test scores of the students in the experimental group in Table 2. Although the overall success of the students in Table 1 did not show a steady increase, the students in the experimental group were observed to receive more significant and successful test scores from week to 
week within 12 weeks. In Table 3, the mean of the weekly scores for both groups for 12 weeks and the overall score for 12 weeks at the end were more clearly shown. Accordingly, the total score of the control group students at 12 weeks is 71 out of 100 and 79 out of 100 of the experimental group students.

It is clear that the experimental group students are more successful in comparing the average of the two groups with the weekly averages and also the average of the 12 week averages; the use of cultural items in the course and classroom environment for foreign language teaching influenced the results of the students positively and the students became more motivated to learn target foreign language with cultural elements, objects and activities in target foreign language learning.

\subsection{Feedbacks - Evaluation}

This evaluation includes the feedbacks and comments of experiment group students after applying Study of the influence of cultural items on foreign language teaching and student motivation. In this part, the educator who entered the course and the students of the 5 experimental groups' comments were given about the method without changing their ideas. (See Appendix A).

Educator:

My specialty is teaching a foreign language and teaching a foreign language to another human being is a very difficult and complicated work. Because language is the first element of communication, it is a source of life and culture in itself. Language is the interpreter of people's understanding of life, customs and all experiences from the past. So language is not just a form of language or words in certain rules. Culture, which is the greatest factor in language, has a very great place in language teaching. It was a really beautiful and enjoyable experience to study for 12 weeks in a classroom environment where the cultural elements and objects are intertwined. I can say with certainty that cultural objects starting from the door of the class and belonging to the target language in the class motivate me and the students positively. Especially, I have experienced the different subjects in the textbook in a synchronized classroom environment and I have once again experienced how important and motivating it is to feel the cultural structure of the foreign language in the classroom. I have also noticed the same feelings in my activities in different activities and classroom activities and I am very happy about it. As a result, a more successful class note graph confirmed my thoughts statistically.

Student 1 (T.E.A)

I know English at a certain level and I can speak and express myself, but for the first time in these 12 weeks I felt English language as well as learning English. I especially liked the posters in the class. Afterwards, in a group study, we prepared a poster related to the American Freedom Monument, and my group was selected as winner and it was hung. It made me really happy and I exaggerated the work and made posters of many American famous and cultural monuments and architectural works and I will definitely visit some places at the end of the year. Besides, I saw that I am more interested in English. I will never forget the time I spent in such a class. Thanks.

Student 2 (B.B.R)

The first thing I'm going to say is that I feel sorry for my friends who are learning English in other classes. I wish they had such a beautiful and special class in them. I have not been to another class that is so different and English-speaking, and the connections with the activities and environment were very good. I was also very pleased that my father came to class and told us about the photo we had in front of Big 
Ben. This short visit, which only lasted 10 minutes, made me love England and London. I would like to thank our teacher very much. If possible, I will continue my education in English this year. Please! Thank you so much!

Student 3 (S.O.M)

At first such a class actually came a bit strange, even a little bit of childhood maybe ... Because I had never learned English in such a class in my previous education. But from the very first day I was very used to class and even from home I brought a porter tea set from England to my class and my teacher put it on his desk. After I realized that I do not learn English, I use English. English as a lesson entered my life in a different and interesting way, which was a lesson that I thought was just the rules and memorization. Now the English language attracts my attention out of the class too. On social media, while I was writing to my friends, I only used certain patterns and words, and now I have friends from America and England. As I learned the cult of the language, I saw that I had more interest in it. Thank you for letting me learn English in such a class.

Student 4 (A.S.A)

I saw my best friend while he was preparing the class with our English teacher and wondered what they were doing. I then helped them prepare the class. After a while they reported that I was in this class too. At first it seemed like a little game but then I liked the models and small statues in the class. I learned that these were the traditional cultural items that my classmates bought from their visits to England and America. I loved English language before I spend my time here, but for me a in the end it was a class. But it seems that English in this class is no longer only a lesson anymore. The activities we have made in the classroom and the guests etc. led me to learn this language better and to do something outside the classroom too. For example, I love listening to music and I collect lyrics written in English now. There is now a small archive of 500 lyrics written in English. Of course, this contributes directly to my English.

Student 5 (M.S.E)

It cannot be said that I have interest in English or a foreign language. I had heard from my friends that they were designing a new English language class and I had a little curiosity about how it was. I was so glad that I got the chance to become a student in that class. I love everything that is new and modern and I thought that it would be a very different design in this class and it happened. There were many cultural objects, posters, and items belonging to England and America that were not included in other class. I could not make any sense at first, but in time I learned to touch the modern elements of the traditional language of the language I learned, and I realized that my interest in English language and lessons increased. I guess the classroom environment was not like the other classrooms, it was like an English language kayak (ship). Throughout the course of time activities and cultural objects that we have established in connection with the English perspective has been involuntarily changed in the positive direction. I now love and interest English more. Therefore, I am very grateful to my teacher who gave me this chance in this class.

\subsubsection{Evaluation of Student Feedbacks}

At the end of the twelve-week training period, it was understood from the feedback of the students and the comments they wrote that they were generally more efficient than the lessons and that the students adopted a class in which the culture of the target language was used in the classical class setting. Students have stated that the use of cultural items with different activities in the lessons motivate them more in the 
learning the target language. In other words, the cultural elements and objects used in foreign language learning have shown that most of the students enjoy the lessons they have made and thus are more successful with high adaptation and motivation.

\section{References}

Apte, M. (1994). Language in sociocultural context. In: R. E. Asher (Ed.), The encyclopedia of language and linguistics. Vol.4 (pp. 2000-2010). Oxford: Pergamon Press.

Brooks, N. (1986). Culture in the Classroom, Culture bound, Ed. by. Joyce Merrill Valdes, Cambridge University Press, pp. 123-129.

Brown, H.D. (1994). Teaching by principles. Englewood Cliffs, NJ: Prentice Hall.

Byram, M., Morgan, C. and Colleagues. (1994). Teaching and learning language and culture. Great Britain: WBC.

Byram, M. (1989). Cultural studies in foreign language education. Clevedon \& Philadelphia: Multilingual Matters Ltd.

Clement, R., Dörnyei, Z., \& Noels, K. A. (1994). Motivation, self-confidence and group cohesion in the foreign language. Language Learning, 44, 417-448.

Crookes, G., \& Schmidt, R. W. (1991). Motivation: reopening the research agenda. Language Learning, 41, 469-512.

Dörnyei, Z., \& Otto, I. (1998). Motivation in action: A process model of L2 motivation. Working Papers in Applied Linguistics, 4, 43-69.

Dörnyei, Z. (1994a). Motivation and motivating in the foreign language classroom. Modern Language Journal, 78, 273-284.

Dörnyei, Z. (1994b). Understanding L2 motivation: On with the challenge! Modern Language Journal, 78,273-284.

Gardner, R. C., \& Lambert, W. E. (1972). Attitudes and motivation in second language learning. Rowley, MA: Newbury House.

Gardner, R.C., \& Tremblay, P.F (1994). On motivation, research agendas and theoretical frameworks. Modern Language Journal, 78, 359-368.

Halliday, M.A.K. (1978). Language as social semiotic: The social interpretation of language and meaning. Sydney: Edward Arnold.

İşeri, K. (1996). Dilin Kazanımı ve Yabanc1 Dil Ögretimi. Dil Dergisi, 43, 21-27.

Kramsch, C. (1993). Context and culture in language teaching. Oxford: Oxford University Press.

McCombs, B. L., \& Pope, J. E. (1994). Motivating hard to reach students. Washington, D. C. American Psychological Association.

Odabaşı, H. F. (1997). Yabancı dil öğretiminde bilgisayar kullanımı. Eskişehir.

Oxford, R. L., \& Shearin, J. (1994). Language learning motivation: expanding the theoretical framework. Modern Language Journal, 78, 12-28.

Peck, D. (1998). Teaching culture: Beyond language. Yale: New Haven Teachers Institute.

Pintrich, P. L., \& Schunk, D. H. (1996). Motivation in education: Theory, research and applications. Englewood Cliffs, NJ: Prentice Hall.

Sapir, F. (1970). Culture, language and personality: Selected essays. Edited by Mandesbaum D.G. Berkeley, Cal: University of California Press.

Singhal, M. (1998). Teaching culture in the foreign language classroom. Thai TESOL Bulletin, 11 (1).

Skehan, P. (1991). Individual differences in second language learning. Studies in Second Language Acquisition, 13, 275-298.

Spencer-Oatey, H. (2008). Culturally speaking. culture, communication and politeness theory. 2nd edition. London: Continuum.

Straub, H. (1999). Designing a cross-cultural course. English Forum, 37 (3). 
Tyler, R.W. (1870). Basic principles of curriculum and instruction Chicago. University of Chicago Press.

Yavuz, M.A. (1999). İletişim Kuramı Açısından Dil Öğretimi ve Dil Öğretiminde Güdülemenin Önemi. Dokuz Eylül Üniversitesi Sosyal Bilimler Enstitüsü Dergisi, 1(5), 107.

Zegarac, V. (2007). A cognitive pragmatic perspective on communication and culture. In Kotthoff, H \& Spencer-Oatey (Eds). Book of intercultural communication. Berlin: Walter de Gruyter, pp. 31-53.

\section{Appendix A}

Dear Participants,

In order to develop your second foreign language within the classroom, you have experienced a different classroom environment with cultural objects and materials. We asking to share with us positive and negative opinions about the aspects of this cultural atmospheric. Thank you for participating in this evaluation questionnaire.

(Depending on your request, Name and Surname) 